\title{
Gender Equality in Prespective Islam and Law of Indonesia
}

\author{
H.A. Mufrod Teguh Mulyo \\ Universitas Nahdlatul Ulama Surakarta \\ \{mufrodteguh1983@gmail.com\}
}

\begin{abstract}
Islam explicitly places women on an equal footing with men, namely the position of humans, creations and servants of Allah SWT. Islam teaches that the origin of the creation of man and woman is the same, that is, both from the ground, so it is completely unreasonable to view women as inferior to men. Talking about gender equality in Islam, it is found that a number of verses in the al-Qur'an mention; equality of men and women as servants of Allah, equality of men and women as kholifah on earth, equality of men and women accepting primordial agreements, equality of men and women to achieve achievement, equality of men and women in forming a family, equality of men and women in continuing offspring through legal marriages, equality of men and women in the process of creation. The legal system in Indonesia textually normatively recognizes equal rights and obligations as well as opportunities for women and men. The 1945 Constitution as the highest law does not differentiate the position of women and men. Article 27 paragraph (1) menegaskan persamaan kedudukan laki-laki dan perempuan didepan hukum, sebagai berikut: Segala warga Negara bersamaan kedudukannya di dalam hukum dan pemerintahan dan wajib menjunjung hukum dan pemerintahan itu dengan tidak ada kecualinya.
\end{abstract}

Keywords: Islam, Gender and Legislation

\section{Introduction}

Islam is a universal religion in which it teaches justice for its people, this has been practiced by the prophet Muhammad SAW as a recipient of a mandate from Allah SWT to be conveyed to his people to be carried out in everyday life. As a religion of humanity, Islam puts humans in a very noble position. Humans are described by the al-Qur'an as being very perfect.

Men and women in the view of Islam, that everything was created by Allah with the nature of "Sesungguhnya segala sesuatu, Kami ciptakan dengan Qodar" QS. Al Qomar/54: 49 [1]. QS. Al Qomar / 54: 49. Qodar here is defined as "the standards, attributes that Allah has established for all things" and that is Qodrat. Thus, men or women as individuals and gender have their respective natures. There is no denying that there is a difference between women and men, that is the nature of each. This difference is at least from a biological perspective, the al-Qur'an warns: "jangan kamu iri hati terhadap keistimewaan yang dianugerahkan Allah terhadap sebagian kamu atas sebagian yang lain, laki-laki mempunyai hak atas apa yang 
diusahakannya, dan perempuan juga mempunyai hak atas apa yang diusahakannya. QS. An Nisaa'/4:32 [2].

The verse above implies a difference, and each one has its specialty. However, this verse does not explain what the features and differences are. However, it can be ascertained that the differences that exist certainly result in differences in the main functions that each of them must carry. The difference in the level of intelligence and the ability to think between the sexes. al-Qur'an praises "Ulul-albab", namely those who dhikr and think about the events of heaven and earth, dhikr and thought that can lead people to know the secrets of the universe. Ulu 'l-albab is not limited to men only, but also women, because after the Koran describes the characteristics of Ulu' l-albab, he emphasizes that: "'Maka Tuhan mereka memperkenankan permohonannya (dengan berfirman): "sesungguhnya Aku tidak menyia-nyiakan amal orangorang yang beramal di antara kamu, baik laki-laki atau perempuan...." QS. Ali Imron / 3: 195 [3]. Islam explicitly places women on an equal footing with men, namely the position of humans, creations and servants of Allah SWT. Islam teaches that the origin of the creation of man and woman is the same, that is, both from the ground, so it is completely unreasonable to view women as inferior to men.

As human beings, women have the same rights and obligations to perform worship as men. Women are also recognized as having the right and obligation to improve their quality through increasing knowledge and piety, as well as the obligation to carry out humanitarian tasks which in Islam are called "Amar ma'ruf nahi munkar" towards the creation of a just, peaceful and prosperous society. However, in the sociological reality in society, women are often treated unequally with men. This unequal condition arises because society has been confined to patriarchal values and gender-biased values for too long in seeing the power relations between men and women. Patriarchal values always demand public recognition of male power and everything that is male. In the view of patriarchy, men and women are two different types of creatures, so that both need to be made strict spatial segregation; men occupy the public space, while women are sufficient in the domestic space. The position of women is only subordinate to men. Therefore, it is imperative to provide new insights that are more humanist and more gender sensitive to religious leaders, men and women, so that in turn, there will be awareness among them about the need for reinterpretation of religious teachings and laws that talk about gender relations.

In Muslim societies like Indonesia, Islam is the nation's normative framework because of the majority of its adherents. Therefore, the construction of gender and the construction of sexuality is heavily influenced by the thinking and understanding of religion that develops in society. According to Siti Ruhaini, the entry of Islam to the archipelago was peaceful and gradual, allowing a cross-cultural process between Islam and local culture which in turn formed a distinctive pattern of religious understanding [4]. Since fifteen centuries ago, Islam has eliminated discrimination based on sex. Whereas if there are differences between men and women due to their respective functions and roles, then these differences need not result in one having an advantage over the other, but rather to help, protect and complement each other.

\section{Method}

The method used in this research is a normative legal method. Normative legal research is a scientific research procedure to find the truth based on the scientific logic of law from the normative side. The scientific logic that is consistent in normative legal research is built on the basis of scientific disciplines and the workings of normative legal science, namely the science 
of law whose object is law itself [5]. The data collection technique used in this study used documentation, while the analysis used in this study was descriptive qualitative. The analysis was carried out. First, collecting the verses of the Koran and the legislation which was the object of the research. Second, presenting data related to gender issues and third, drawing conclusions as a research report.

\section{Discussion}

\subsection{Gender in Islamic Prespective}

The term gender must be distinguished from gender (sex). Gender refers to the differences in roles between women and men that are shaped by culture. Meanwhile, sex has a biological understanding of the sex differences between men and women. Nasaruddin Umar emphasized that the differences between men and women still have several problems, both in terms of the substance of the incident and the role that is carried out in society. The biological anatomical differences between the two are quite clear. However, the effect that arises from these differences raises debate, because it turns out that biological sex differences (sex) give birth to a set of cultural concepts. This cultural interpretation of gender differences is called Gender [6].

In the Women's Study Encyclopedia, it is explained that gender is a cultural concept that seeks to make distinctions in terms of roles, behavior, mentality, and emotional characteristics between men and women that develop in society [7]. These differences have long been embedded in the general view of society, giving birth to the notion that these differences in roles are natural and have led to imbalances in the patterns of social relationships and roles between men and women. The concept of culture which has been considered natural can be seen from the general assumption, for example that women are identical to household affairs alone, while men are otherwise identical to managers and people in charge of economic affairs. This assumption is completely a cultural product of humans at a certain period, not something natural that cannot be changed.

According to Mansour Fakih, the history of gender differences between men and women occurs through a very long process. Therefore the formation of gender differences is due to many things, including being formed, socialized, strengthened, even socially or culturally constructed, through religious or state teachings. Through a long process, this gender socialization is finally considered to be God's stipulation - as if it is an irreversible biological nature, so that gender differences are considered and understood as the nature of men and women [8]. Talking about gender equality in Islam, it is found that a number of verses in the al-Qur'an mention:

a. The equality of man and woman as servants of God

"Hai manusia, Sesungguhnya kami menciptakan kamu dari seorang laki-laki dan seorang perempuan dan menjadikan kamu berbangsa - bangsa dan bersuku-suku supaya kamu saling kenal-mengenal. Sesungguhnya orang yang paling mulia diantara kamu disisi Allah ialah orang yang paling taqwa diantara kamu. Sesungguhnya Allah Maha mengetahui lagi Maha Mengenal”. QS. Al Hujarat/49:13. [9]

b. The equality of men and women as caliphs on earth.

"Dan dia lah yang menjadikan kamu penguasa-penguasa di bumi dan dia meninggikan sebahagian kamu atas sebahagian (yang lain) beberapa derajat, untuk mengujimu tentang apa yang diberikan-Nya kepadamu. Sesungguhnya Tuhanmu amat cepat 
siksaan-Nya dan Sesungguhnya dia Maha Pengampun lagi Maha Penyayang”. QS. Al An'am/6:165 [10]

c. Equality of men and women receiving primordial covenants

"Dan (ingatlah), ketika Tuhanmu mengeluarkan keturunan anak-anak Adam dari sulbi mereka dan Allah mengambil kesaksian terhadap jiwa mereka (seraya berfirman): "Bukankah Aku ini Tuhanmu?" mereka menjawab: "Betul (Engkau Tuhan kami), kami menjadi saksi". (Kami lakukan yang demikian itu) agar di hari kiamat kamu tidak mengatakan: "Sesungguhnya kami (Bani Adam) adalah orang-orang yang lengah terhadap ini (keesaan Tuhan)", QS. Al A'raf/7:172 [11]

d. Equality of men and women to achieve achievement

"Maka Tuhan mereka memperkenankan permohonannya (dengan berfirman): "Sesungguhnya Aku tidak menyia-nyiakan amal orang-orang yang beramal di antara kamu, baik laki-laki atau perempuan, (karena) sebagian kamu adalah turunan dari sebagian yang lain. Maka orang-orang yang berhijrah, yang diusir dari kampung halamannya, yang disakiti pada jalan-Ku, yang berperang dan yang dibunuh, Pastilah akan Ku-hapuskan kesalahan-kesalahan mereka dan Pastilah Aku masukkan mereka ke dalam surga yang mengalir sungai-sungai di bawahnya, sebagai pahala di sisi Allah. dan Allah pada sisi-Nya pahala yang baik." QS. Ali Imran/3:195 [12]

e. The equality of men and women in forming a family

"Hai sekalian manusia, bertakwalah kepada Tuhan-mu yang Telah menciptakan kamu dari seorang diri, dan dari padanya Allah menciptakan isterinya; dan dari pada keduanya Allah memperkembang biakkan laki-laki dan perempuan yang banyak dan bertakwalah kepada Allah yang dengan (mempergunakan) nama-Nya kamu saling meminta satu sama lain, dan (peliharalah) hubungan silaturrahim. Sesungguhnya Allah selalu menjaga dan Mengawasi kamu." QS. An-Nisaa/4:1. [13]

f. The equality of men and women in continuing their offspring through a legal marriage. "Dialah yang menciptakan kamu dari diri yang satu dan dari padanya dia menciptakan isterinya, agar dia merasa senang kepadanya. Maka setelah dicampurinya, isterinya itu mengandung kandungan yang ringan, dan teruslah dia merasa ringan (beberapa waktu). Kemudian tatkala dia merasa berat, keduanya (suami-isteri) bermohon kepada Allah, Tuhannya seraya berkata: "Sesungguhnya jika Engkau memberi kami anak yang saleh, tentulah kami termasuk orang-orang yang bersyukur". QS. Al A'raf /7:189. [14]

g. The equality of men and women in the process of creation

"Dia-lah yang menciptakan kamu dari tanah Kemudian dari setetes mani, sesudah itu dari segumpal darah, Kemudian dilahirkannya kamu sebagai seorang anak, Kemudian (kamu dibiarkan hidup) supaya kamu sampai kepada masa (dewasa), Kemudian (dibiarkan kamu hidup lagi) sampai tua, di antara kamu ada yang diwafatkan sebelum itu. (Kami perbuat demikian) supaya kamu sampai kepada ajal yang ditentukan dan supaya kamu memahami(nya)”. QS. Al Mu’min/40:67. [15]

The verses above emphasize that in terms of equality and the essence of creation, there is no difference between one human and another, including between women and men. Therefore, there is no need for any kind of superiority of a group, ethnicity, nation, race, or gender entity to another. This similarity in biological origins indicates similarities between humans, including equality between women and men. The explanation above concludes that the Koran affirms the equality of women and men. In line with the Qur'an, a number of the Prophet's hadiths also state that women are equal to male counterparts [16]. 
Thus, in essence humans are the same and equal, they are brothers and one family. Although both biologically; Men and women are different as stated in the Koran, but physical differences should not be used as an excuse to discriminate against women. Sex differences are not an excuse to discredit women and privilege men. Biological differences should not become the basis for placing women in a subordinate position and men in a superordinate position. The natural differences between men and women should lead humans to the awareness that men and women have differences and with the provision of these differences both are expected to help each other, love and complement each other. Therefore, the two of them must work together so that a peaceful society can be created.

\subsection{Gender in the prespective of Indonesian Legislation}

In principle, Indonesia's legal and political system also textually normatively recognizes equal rights and obligations as well as opportunities for women and men. The 1945 Constitution as the highest law does not differentiate the position of women and men. Article 27 paragraph (1) confirms the equal position of men and women before the law, as follows: Segala warga Negara bersamaan kedudukannya di dalam hukum dan pemerintahan dan wajib menjunjung hukum dan pemerintahan itu dengan tidak ada kecualinya.

The next article (28), in the Amendment to the 1945 Constitution also affirms the guarantee of the Law on equality of human rights for both men and women [17] as follows:

\section{Article 28 A}

Setiap orang berhak untuk hidup serta berhak mempertahankan hidup dan kehidupannya

\section{Article 28 B}

(1) Setiap orang berhak membentuk keluarga dan melanjutkan keturunan melalui perkawinan yang sah.

(2) Setiap anak berhak atas kelangsungan hidup, tumbuh dan perkembang serta berhak atas perlindungan dari kekerasan dan diskriminasi

\section{Article 28 C}

(1) Setiap orang berhak mengembangkan diri melalui pemenuhan kebutuhan dasarnya, berhak mendapat pendidikan dan memperoleh manfaat dari ilmu pengetahuan dan teknologi, seni dan budaya,demi meningkatkan kualitas hidupnya dan demi kesejahteraan umat manusia.

(2) Setiap orang berhak untuk memajukan dirinya dalam memperjuangkan haknya secara kolektif untuk membangun masyarakat, bangsa dan negaranya.

\section{Article 28 D}

(1) Setiap orang berhak atas pengakuan, jaminan, perlindungan dan kepastian hukum yang adil serta perlakuan yang sama di hadapan hukum

\section{Article 28 G}

(1) Setiap orang berhak atas perlindungan diri pribadi, keluarga, kehormatan, martabat dan harta benda yang di bawah kekuasaannya, serta berhak atas rasa aman dan perlindungan dari ancaman ketakutan untuk berbuat atau tidak berbuat sesuatu yang merupakan hak asasi 
(2) Setiap orang berhak untuk bebas dari penyiksaan atau perlakuan yang merendahkan derajat martabat manusia dan berhak memperoleh suaka politik dari negara lain.

\section{Article $28 \mathrm{H}$}

(1) Setiap orang berhak hidup sejahtera lahir dan batin, bertempat tinggal dan mendapatkan lingkungan hidup yang baik dan sehat serta berhak memperoleh pelayanan kesehatan

(2) Setiap orang berhak mendapat kemudahan dan perlakuan khusus untuk memperoleh kesempatan dan manfaat yang sama guna mencapai persamaan dan keadilan

(3) Setiap orang berhak atas jaminan sosial yang memungkinkan pengembangan dirinya secara utuh sebagai manusia yang bermanfaat

(4) Setiaporang berhak untuk mempunyai hak milik pribadi dan hak milik tersebut tidak boleh diambil secara sewenang-wenang oleh siapapun

\section{Article 28 I}

(1) Hak untuk hidup, hak untuk tidak disiksa, hak kemerdekaan pikiran dan hati nurani, hak beragama, hak untuk tidak diperbudak, hak untuk diakui sebagai pribadi di hadapan hukum, dan hak untuk tidak dituntut atas dasar hukum yang berlaku surut adalah hak asasi manusia yang tidak dapat dikurangi dalam keadaan apapun.

(2) Setiap orang berhak bebas dari perlakuan yang bersifat diskriminatif atas dasar apapun dan berhak mendapatkan perlindungan terhadap perlindungan yang bersifat diskriminatif.

\section{Article 28 J}

(1) Setiap orang wajib menghormati hak asasi manusia orang lain dalam tertib kehidupan bermasyarakat, berbangsa, dan bernegara

Since 1952 the Indonesian government has ratified the UN convention on the elimination of all forms of discrimination against women (Convention on The Elimination of All Forms of Discrimination Againts Women) in fact legal reform has occurred, marked by the existence of legal instruments that guarantee equality and justice, sourced from various conventions. international, national positive law, including various jurisprudence on cases where women get justice. It is worth mentioning here that guarantees of justice can be sought since Article 27 of the 1945 Constitution [18], various laws and regulations such as the most recent being the Law on the Elimination of Domestic Violence, Law Number 7/1984 as a ratification of the CEDAW convention which very comprehensively regulates the prohibition of discrimination against women in almost all areas of life. In addition, there are various principles and values of justice for women and men that are ensnared in various laws and regulations relating to the recognition of equal position of men and women in rights related to work, educational opportunities and conditions and certainty. law in employment.

Di Indonesia, perjuangan mengangkat harkat dan martabat wanita telah menjalani rentang waktu yang cukup lama. Perjuangan tersebut sudah menembus berbagai sektor antara lain sektor pendidikan dan hukum. Sistem hukum di Indonesia telah mengatur hak memperoleh kesetaraan dan keadilan. UUD 1945 hasil amandemen pasal 28 H (2) menyebutkan, "Setiap orang berhak mendapatkan kemudahan dan perlakuan khusus untuk memperoleh kesempatan dan manfaat yang sama guna mencapai persamaan dan keadilan.” Pasal 28 I (2) menyebutkan, "Setiap orang berhak bebas dari perlakuan yang bersifat diskriminatif atas dasar apapun dan berhak mendapatkan perlindungan terhadap perlakuan yang bersifat diskriminatif itu".

In Indonesia, the struggle to elevate the dignity of women has been going on for quite a long time. This struggle has penetrated various sectors, including the education and legal 
sectors. The legal system in Indonesia has regulated the right to equality and justice. The 1945 Constitution as a result of the amendment to Article $28 \mathrm{H}$ (2) states, "Setiap orang berhak mendapatkan kemudahan dan perlakuan khusus untuk memperoleh kesempatan dan manfaat yang sama guna mencapai persamaan dan keadilan. Article 28 I (2) states, Setiap orang berhak bebas dari perlakuan yang bersifat diskriminatif atas dasar apapun dan berhak mendapatkan perlindungan terhadap perlakuan yang bersifat diskriminatif itu".

Various legislative products have also been stipulated as a realization of the equal position of women and men. The legislative products include: Law no. 1 of 1974, concerning Marriage; UU no. 13 of 2003, concerning Manpower; UU no. 3 of 1997, concerning Child Protection; UU no. 39 of 1999, concerning Human Rights; Presidential Instruction No. 9 of 2000, concerning Justice and Equality; UU no. 23 of 2004, concerning the Elimination of Domestic Violence; UU no. 17 of 2006 concerning Citizenship; Presidential Regulation No. 7 of 2005, concerning the National Medium Term Development Plan; Election Law No.10 of 2008, and Law no. 27 of 2009, concerning the MPR, DPR, DPD and DPRD.

It seems that the struggle of women to obtain equality and fair treatment is more often shown in the law, to examine this problem, this section will describe how the provisions of the laws governing the equality of men and women, namely:

a. The 1945 Constitution (Articles 27-34)

b. MPR Decree Number II / MPR / 1988 and MPR Decree Number II / MPR / 1993,

c. Laws, and

d. Government Regulations

The 1945 Constitution (Articles 27-34) states that citizens have the same status. Explicitly, citizens are not only men, but also women. So, the 1945 Constitution places women and men as equal partners. The MPR decrees are the second level of statutory provisions after the 1945 Constitution.In the two MPR decrees, it can be observed that the role of women in the development of PJPT I and PJPT II, namely MPR Decree number II / MPR / 1988 on point 10, is currently in the MPR decrees. number II / MPR / 1993 in points 9, 13, and 32.

Generrally, men and women are equal partners who complement each other, depend on each other, and need each other. Dignity and dignity can be achieved through persistent struggle, both by men and women, without having to depend on one another. If this understanding is understood by all parties, the statement "in accordance with or with regard to nature, dignity as a woman" no longer needs to be included in the GBHN. The inclusion of this sentence invites an interpretation that the nature, dignity of women is different from that of men, and implies that these differences place women not as equal partners. Women with this difference seem to be inferior to men.

The third level in the sequence of laws regulating the position of men and women is the Marriage Law No.1 of 1974, Law no. 13 of 2003, concerning Manpower; UU no. 3 of 1997, concerning Child Protection; UU no. 39 of 1999, concerning Human Rights; Presidential Instruction No. 9 of 2000, concerning Justice and Equality; UU no. 23 of 2004, concerning the Elimination of Domestic Violence and Law no. 17 of 2006 concerning Citizenship. The fourth level which regulates the position of men and women equally is Presidential Regulation No. 7 of 2005, concerning the National Medium Term Development Plan; Election Law No.10 of 2008; and Law no. 27 of 2009, concerning the MPR, DPR, DPD and DPRD.

\section{Conclusion}

Based on the explanation above, it can be concluded as follows; 
a. First, gender in Islam emphasizes the existence of equality; men and women as servants of Allah, men and women as kholifah on earth, men and women accept primordial agreements, men and women to achieve achievements, men and women in forming families, men and women. women in continuing their offspring through a legal marriage.

b. Second, Gender in Legislation in Indonesia is stated in; The 1945 Constitution (Articles 27-34), MPR Decree Number II / MPR / 1988 and MPR Decree Number II / MPR / 1993, Law No. 1 of 1974, concerning Marriage; UU no. 13 of 2003, concerning Manpower; UU no. 3 of 1997, concerning Child Protection; UU no. 39 of 1999, concerning Human Rights; Presidential Instruction No. 9 of 2000, concerning Justice and Equality; UU no. 23 of 2004, concerning the Elimination of Domestic Violence; UU no. 17 of 2006 concerning Citizenship; Presidential Regulation No. 7 of 2005, concerning the National Medium Term Development Plan; Election Law No.10 of 2008; and Law no. 27 of 2009, concerning the MPR, DPR, DPD and DPRD.

\section{Refereences}

[1] Dz, Siti Ruhaini, "Pengantar”, dalam Islam dan Kontruksi Seksualitas, Yogyakarta: PSW IAIN-The Ford Foundation-Pustaka Pelajar, 2002

[2] Fakih, Mansour, Analisis Gender \& Tranformasi Sosial, Cet. XII, Yogyakarta: Pustaka Pelajar, 2008

[3] Kadarusman, Agama, Relasi Gender dan Feminisme, Yogyakarta: Kreasi Wacana, 2005

[4] Megawangi, Ratna, Membiarkan Berbeda? Sudut Pandang Baru Tentang Relasi Gender, cet. I Bandung: Mizan, 1999

[5] Mulia, Siti Musdah, Islam Menggugat Poligami, Jakarta: PT. Gramedia, 2004

[6] Nashir, Haidar, Agama \& Krisis Kemanusiaan Modern, Yogyakarta: Pustaka Pelajar, 1997

[7] Nasution, Khoiruddin, Status Wanita di Asia Tenggara, Jakarta: INIS, 2002

[8] Prodjodikoro, Wiryono, Hukum Perkawinan di Indonesia, Bandung: Penerbit Sumur, 1974

[9] Shuqqah, Abu, Jati Diri Wanita menurut al-Qur'an dan Hadits, Bandung: Mizan, 1993.

[10] Soenarjo, al-Qur'an dan Terjemahnya, Jakarta: CV Putra Sejati Raya, 2003

[11] Syahbana, "Wanita Indonesia dalam Keluarga: Perspektif Islam", Jurnal Ilmu Syariah Fak Syari'ah Jogjakarta Asy-Syir'ah, Vol.35, No.II Tahun 2001

[12] Thahar, Kamarisah, Wanita dalam Islam, Jakarta: Firma Maju Medan, 1984

[13] Tierney, Helen (ed) Womewn's Studis Encyclopedia, Vol. I, New York: Green Wood Press

[14] Umar, Nasaruddin, Argumen Kesetaraan Jender Perspektif al-Qur'an, Jakarta: Paramadina, 2001

[15] Terjemahan dari Women's Convention, yang sering juga disebut sebagai CEDAW Convention. Konvensi wanita adalah istilah yang resmi digunakan oleh pemerintah/negara ketika meratifikasi konvensi tersebut melalui UU no. 7/1984

[16] Intruksi Presiden RI. No. 1 Tahun 1981, Kompilasi Hukum Islam di Indonesia, Direktorat Pembinaan Peradilan Agama, Dirjen Bimbingan Masyarakat Islam Penyelenggaraan Haji, Departemen Agama, RI. Jakarta, 2002

[17] Ketetapan-ketetapan Sidang Tahunan MPR-RI Tahun 2000, Jakarta: Restu Agung, 2000 
[18] Undang-undang Perkawinan No. 1 tahun 1974 